\title{
Probiotic and formaldehyde treatments of Artemia nauplii as food for larval pollack, Pollachius pollachius
}

\author{
François-Joël Gatesoupe ${ }^{1, *}$ \\ 1 : Unité mixte de Nutrition des Poissons INRA-IFREMER, IFREMER, Centre de Brest, BP 70, 29280 Plouzané, \\ France \\ *: Tel.: +33-2-98-22-43-89; fax: +33-2-98-22-46-53; email: joel.gatesoupe@ifremer.fr
}

\begin{abstract}
:
Formaldehyde was used to disinfect Artemia cysts and nauplii, while introducing two probiotics in the enrichment process: Bactocell (Pediococcus acidilactici) and Levucell (Saccharomyces cerevisiae). The disinfectant was selected due to its potential compatibility with probiotics, since it was more effective against Gram-negative bacteria than against lactic acid bacteria and yeast. However, the presence of formaldehyde reduced the intake of $P$. acidilactici in Artemia. Consequently, the disinfection was stopped before Bactocell supplementation to the nauplii fed to pollack (Pollachius pollachius) larvae. The mean weight of pollack was higher with this probiotic treatment. Growth was even better with the combination of Levucell and Bactocell, but the yeast should be introduced circumspectly. A high bacterial load was found in the nauplii enriched with Levucell, but not treated with formaldehyde. In the absence of Bactocell, the discontinuation of disinfecting Artemia after Levucell enrichment caused poor growth of pollack.
\end{abstract}

Resistant strains had emerged after 3 months of daily cyst incubation with $50 \mathrm{mg} \mathrm{I}^{-1}$ formaldehyde, rising from 1.4 CFU per newly hatched nauplius before the experiments, up to $3.4 \times 10^{4} \mathrm{CFU}$ nauplius ${ }^{-1}$ by the end of 3 months. The phenotypes and genotypes of these opportunistic resistant strains were quite different from the initial resistant strains. Particular attention was paid to Vibrio alginolyticus-like isolates that were not detected before the experiments. These isolates were compared by amplified ribosomal DNA-restriction analysis (ARDRA) and RAPD to two reference strains previously isolated in turbot larvae, indicating some genotypic distance between the new isolates and the reference strains. Thus, the formaldehyde treatment cannot be recommended due to the risk of resistance spread.

It was concluded that $P$. acidilactici is a promising probiotic for fish larvae. Its combination with $S$. cerevisiae may be valuable, but on the condition that a concentrated form that would not jeopardize the bacterial balance in the absence of disinfectant should be prepared. 


\section{Introduction}

A preliminary study has shown an interest of pollack as candidate species for aquaculture in the temperate Atlantic coast of Europe (Suquet, 2001). The first attempts of larval rearing were promising (Suquet et al., 1996), and it could serve as a model to improve the rearing technique for cod and other Gadidae considered to be difficult to rear like saithe (Pollachius virens; van der Meeren and Lønøy, 1998).

Schrøder et al. (1980) isolated a lactic acid bacterium from the gut of saithe, which inhibited in vitro the growth of Vibrio sp. This pioneering study pointed out the ecological importance of such bacteria in gut microbiota of Gadidae. Gildberg et al. (1997), then Gildberg and Mikkelsen (1998) evidenced the probiotic effect of lactic acid bacteria in cod fry. In aquaculture, autochthonous probiotics have been generally preferred to commercial preparations designed for man and terrestrial livestock (Gatesoupe, 1999). However, there is a renewal of interest for such products already documented as safe foodstuff, and immediately available for every fish farms and hatcheries. For instance, Nikoskelainen et al. (2001a) investigated the potential probiotic properties of seven lactic acid bacteria intended for human or land animal use, by studying their capacities of adhesion and penetration into fish mucus, their inhibitory effect against fish pathogens, and their resistance to fish bile. The same authors showed the protective effect of one of these strains, Lactobacillus rhamnosus, against furunculosis in rainbow trout (Nikoskelainen et al., 2001b).

The present study aimed to study the effects of two commercial probiotic strains that were introduced into pollack larval microbiota via Artemia nauplii. These products designed for land animals contained either lactic acid bacteria, Pediococcus acidilactici, or yeast, Saccharomyces cerevisiae. Both species have been also described as being harbored in fish microbiota, where they may present some probiotic features, like the bacteriocin production 
of P. acidilactici (Halami et al., 1999), and the colonization potential of S. cerevisiae (Andlid et al., 1999). Both can survive in seawater, and non-autochthonous strains of S. cerevisiae adhered to the gut of European sea bass larvae (Tovar et al., 2000). Moreover, the combination of probiotics with different mode of action is theoretically interesting (FilhoLima et al., 2000). To my knowledge, the synergistic effect of lactic acid bacteria and yeast has not been demonstrated, though commercial mixtures are available. Such a preparation with Lactobacillus coagulans and S. cerevisiae was efficient to increase the growth rate of tropical freshwater fish larvae and fry (Mohanty et al., 1996; Swain et al., 1996).

The bacterial load is quite high in newly hatched Artemia nauplii (Lavens and Sorgeloos, 2000). Verschuere et al. (1999) proposed to control the microbial environment of Artemia by cyst disinfection, then by preemptive inoculation of selected bacterial strains into the rearing water. Sahul Hameed and Balasubramanian (2000) recommended to disinfect the nauplii with formaldehyde before introduction into the rearing systems. In case of probiotic treatment, a particular interest of this disinfectant might be its efficiency stronger against gram-negative bacteria than against gram-positive bacteria and fungi (Spicher and Peters, 1976). Most bacteria are gram-negative in marine fish and shellfish microbiota, and formaldehyde could favor the artificial colonization by probiotic yeast or lactic acid bacteria. We have thus tried to use formaldehyde in combination with the introduction of probiotics. However, some gramnegative bacterial strains are known to resist to formaldehyde disinfection because of a plasmidic resistance gene (Kümmerle et al., 1996). It was therefore important to check whether the formaldehyde treatment could cause resistance spread.

The experimental design was thus split into three steps: (1) the bacterial characterization of Artemia nauplii treated with formaldehyde and with the probiotics, (2) the application of the treatments to pollack larvae, and (3) a bacteriological survey of formaldehyde resistant strains before and after the experiments. 


\section{Materials and methods}

\subsection{Microbial study of Artemia cysts and nauplii}

Artemia cysts (INVE, AF lot 01.27C) were incubated in strongly aerated seawater at $28^{\circ} \mathrm{C}$, while disinfecting with $50 \mathrm{mg} \mathrm{l}^{-1}$ formaldehyde, unless other specified. After $20 \mathrm{~h}$ incubation, the nauplii were harvested by sieving between two plankton nets (100 $\mu \mathrm{m}$ and $212 \mu \mathrm{m}$ mesh). The initial effect of formaldehyde disinfection on bacterial load was analyzed by counting bacteria associated with nauplii, after a cyst incubation test with 0,50 and $100 \mathrm{mg} \mathrm{l}^{-1}$ formaldehyde, with four replicates per treatment. After three months of daily cyst disinfection, the bacteria were counted in a similar incubation test, with an additional treatment at $75 \mathrm{mg} \mathrm{l}^{-1}$ formaldehyde. To this end, the cysts were dispatched into $500 \mathrm{ml}$ flasks with aeration, at the rate of $1 \mathrm{~g} \mathrm{l}^{-1}$. The bacteria were counted in newly hatched nauplii with the method used previously for rotifers (Gatesoupe, 1990). In addition to Petrifilm counts (Aerobic Count Plates, 3M Microbiology Products), the population of Vibrio was approximated by counting thiosulfate-citrate-bile salt agar plates( TCBS, AES Laboratoire, dissolved in half-strength seawater equivalent to 18 practical salinity units).

The initial and final resistant strains were sampled by isolating colonies on Petrifilm. The isolates were cultivated on plate count agar (PCA, AES Laboratoire, enriched with $18 \mathrm{~g} \mathrm{l}^{-1}$ $\mathrm{NaCl}$, with the $\mathrm{pH}$ adjusted to 7.8), and then they were stored under liquid nitrogen. The phenotypes were compared with API 20 E strips according to the manufacturer's instructions (bioMérieux). The API 20 E profiles were computed with Mix and Drawtree of Phylip (Felsenstein, 1996). 
The genotypes were compared by amplified ribosomal DNA-restriction analysis (ARDRA, Dees and Ghiorse, 2001). Briefly, DNA was prepared for PCR, then the 16S rDNA gene was amplified with the universal primers SA-dir (5'-AGAGTTTGATCATGGCTCAG-3') and S17-rev (5'-GTTACCTTGTTACGACTT-3'), as described by Lambert et al. (1998). Two aliquots of the PCR product were incubated for $2 \mathrm{~h}$ at $37^{\circ} \mathrm{C}$ with (1) Hae III and (2) Cfo I, plus the respective buffers provided by the manufacturer (Sigma). The Vibrio isolates were compared to 2 reference strains that were closely related: VM2, formerly "vibrio E" (Gatesoupe, 1997), and V16 which was isolated once from healthy turbot larvae at 8 day posthatching (dph) during an experiment of rotifer treatment with VM2 (unpublished data). These Vibrio strains were compared by RAPD (Gatesoupe et al., 1999), and they were cultured on PCA with 0,50 and $100 \mathrm{mg} \mathrm{l}^{-1}$ formaldehyde.

The two probiotic preparations tested were Levucell SB 20 (Saccharomyces cerevisiae I1079, CNCM, Institut Pasteur, Paris), and Bactocell (Pediococcus acidilactici CNCM MA 18/5M). Newly hatched nauplii were introduced into $500 \mathrm{ml}$ bottles containing $400 \mathrm{ml}$ seawater (100 nauplii $\mathrm{ml}^{-1}$ ). The nauplii were starved for $6 \mathrm{~h}$, then they were enriched for $14 \mathrm{~h}$ with the self-emulsifying concentrate of essential fatty acids DHA Selco (INVE, $150 \mathrm{mg} \mathrm{l}^{-1}$ ), with or without $50 \mathrm{mg} \mathrm{l}^{-1}$ formaldehyde, and with or without $50 \mathrm{mg} \mathrm{l}^{-1}$ of one of the probiotic preparations, corresponding to ca. $10^{9} \mathrm{CFU} \mathrm{l}^{-1}$ of $S$. cerevisiae, or ca. $10^{10} \mathrm{CFU} \mathrm{l}^{-1}$ of $P$. acidilactici. After enrichment, the bacteria associated with Artemia were counted on Petrifilm and TCBS plates. Two other specific media were used to count the probiotics: Sabouraud agar (AES Laboratoire) supplemented with antibiotics (chloramphenicol, $1 \mathrm{mg} \mathrm{l}^{-1}$; Polymixin B sulfate, $0.8 \mathrm{mg} \mathrm{l}^{-1}$; Amoxicillin, $1.25 \mathrm{mg} \mathrm{l}^{-1}$ ) to count the yeast after $48 \mathrm{~h}$ of incubation at $30^{\circ} \mathrm{C}$, and MRS agar (AES Laboratoire) to count P. acidilactici after $48 \mathrm{~h}$ of incubation at $45^{\circ} \mathrm{C}$. 


\subsection{Larval rearing experiments}

Pollack (Pollachius pollachius) larvae were reared in $150 \mathrm{l}$ tanks with conical bottom. The newly hatched larvae were introduced into 18 tanks at the concentration of 28 larvae ${ }^{-1}$. The initial temperature was $11.8^{\circ} \mathrm{C}$, and it was progressively increased up to $15.1 \pm 1^{\circ} \mathrm{C}$ at 9 day post hatching (dph) onwards. The water supply was introduced at the bottom of the tanks at the rate of $1 \mathrm{l} \mathrm{mn}^{-1}$ from 1 to $11 \mathrm{dph}$, according to the recommendation of Gaignon et al. (1998). A tangential water supply was then showered at the surface at the rate of $500 \mathrm{ml} \mathrm{mn}^{-1}$ from 8 to $11 \mathrm{dph}$, then $1.5 \mathrm{l} \mathrm{mn}^{-1}$ from $12 \mathrm{dph}$ onwards. The water surface was cleaned with the device of Chatain and Ounais-Guschemann (1990).

The food sequence was adapted from Suquet et al. (1996). The larvae were fed with rotifers Brachionus rotundiformis from 3 to $11 \mathrm{dph}$ at the rates of 20-200 rotifers per $1 \mathrm{dph}$ larva. The rotifers were cultured with live bakers yeast $\left(60 \mathrm{mg} \mathrm{l}^{-1}\right.$ day $^{-1}$, on a dry matter basis), DHA Selco (18 $\mathrm{mg} \mathrm{l}^{-1}$ day $^{-1}$ ), and T-Isochrysis affinis galbana (ca. $2 \times 10^{5}$ cells $\mathrm{mL}^{-1} \mathrm{day}^{-1}$ ). Then, they were transferred into clean seawater (200 rotifers $\mathrm{ml}^{-1}$ ), enriched with DHA Selco (18 mg $\mathrm{l}^{-1}$ ), and distributed continuously into the larval rearing tanks with a peristaltic pump (Gatesoupe, 1990).

Newly hatched Artemia nauplii were introduced into the larval rearing tanks from 8 to $12 \mathrm{dph}$ (1-30 nauplii per $1 \mathrm{dph}$ larva).

From 13 dph onwards, the nauplii were further treated for one day with six experimental enrichments. To this end, the nauplii were introduced into enrichment tanks at the rate of 20 nauplii $\mathrm{ml}^{-1}$, and treated with formaldehyde $\left(50 \mathrm{mg} \mathrm{l}^{-1}\right)$. After $6 \mathrm{~h}$ of starvation, the nauplii were enriched for $14 \mathrm{~h}$ with DHA Selco $\left(150 \mathrm{mg} \mathrm{l}^{-1}\right.$ ), and either brewers dried yeast (inactive food ingredient, $50 \mathrm{mg} \mathrm{l}^{-1}$, treatments BC, BL and BP) or the probiotic preparation Levucell 
(50 $\mathrm{mg} \mathrm{l}^{-1}$, treatments LC, LL and LP). This $14 \mathrm{~h}$ phase was designated as the first step of enrichment. The $1 \mathrm{dph}$ Artemia were then distributed continuously with a peristaltic pump, and further enriched with DHA Selco $\left(50 \mathrm{mg} \mathrm{l}^{-1}\right)$. Depending on the experimental treatment, this second step of the enrichment process included no probiotic (treatments BC and LC), or either Levucell (50 $\mathrm{mg} \mathrm{l}^{-1}$, treatments BL and LL) or Bactocell (50 $\mathrm{mg} \mathrm{l}^{-1}$, treatments BP and LP). When Levucell was used during the second step of enrichment, the distribution medium was again treated with formaldehyde (50 $\mathrm{mg} \mathrm{l}^{-1}$, treatments BL and LL).

The amounts of 1dph Artemia were adjusted daily for each treatment, according to the amounts remaining in the larval rearing tanks (from 5 to 120 nauplii per 1 dph larva). The food amounts could not be adjusted independently for each replicate, because the larval tanks were fed from one enrichment tank per treatment. For each treatment, the total amount of 1 dph Artemia distributed to the larvae from 13 dph onwards was added up, and then divided by the number of larvae surviving at $29 \mathrm{dph}$.

The six enrichment treatments were dispatched at random in triplicates among the 18 larval rearing tanks. Thirty larvae were sampled per tank at 13 and 29 dph, to estimate the mean weights before and by the end of the experimental feeding period. At $28 \mathrm{dph}$, five larvae were sampled per tank. They were transferred to a solution of $0.1 \%$ benzalkonium chloride for surface disinfection, then rinsed with seawater under sterile conditions (Skjermo and Vadstein, 1993). Then associated microbes were counted as described for Artemia.

The data were compared by analysis of variance (ANOVA), after checking normality and variance homogeneity. When both tests were passed, the effects of the individual treatments were assessed by an a priori test (Sokal and Rohlf, 1969), in case of significant difference. When one or both tests failed, ANOVA on ranks (Kruskall-Wallis) was applied, followed by the Student-Newman-Keuls test for significant differences. 


\section{Results}

\subsection{Microbial study of Artemia cysts}

There was a strong initial effect of formaldehyde treatment of Artemia cysts on bacterial counts, but not significant effect on hatching rate (Table 1). Only 0.7 CFU nauplius ${ }^{-1}$ was recovered on Petrifilm after cyst incubation with $100 \mathrm{mg} \mathrm{l}^{-1}$ formaldehyde. Thirteen colonies were isolated for further characterization. The bacterial concentration was double with $50 \mathrm{mg}$

$\mathrm{l}^{-1}$ formaldehyde, but this was still negligible in comparison with the $2 \times 10^{4} \mathrm{CFU}$ nauplius ${ }^{-1}$ retrieved with the control incubation without formaldehyde. Colonies growing on TCBS agar were retrieved only in the control group.

After the cysts had been daily disinfected with $50 \mathrm{mg} \mathrm{l}^{-1}$ formaldehyde for three months, the bacterial concentration on Petrifilm was 3.4 x $10^{4}$ CFU per nauplius hatched from cysts treated with $50 \mathrm{mg} \mathrm{l}^{-1}$ formaldehyde, and still $161 \mathrm{CFU}$ nauplius ${ }^{-1}$ with $75 \mathrm{mg} \mathrm{l}^{-1}$ formaldehyde. No culturable bacterium was detected with $100 \mathrm{mg} \mathrm{l}^{-1}$ formaldehyde (detection threshold: 0.7 CFU nauplius ${ }^{-1}$ ).

Among the colonies recovered after the treatment with $50 \mathrm{mg} \mathrm{l}^{-1}$ formaldehyde, 21 isolates were further characterized, and compared with the 13 initial isolates resistant to $100 \mathrm{mg} \mathrm{l}^{-1}$ formaldehyde.

The phenotypes of both series of isolates were quite different, as illustrated by the dendrogram obtained with their API 20 E profiles (Fig. 1). A particular attention was paid to the swarming strains VA75S3 and VAPFS4. Their profiles corresponded to Vibrio alginolyticus, and they were compared to the reference strain V16 that matched profile 
VAPFS4. The second reference strain VM2 had a distinct profile. The four strains were completely inhibited by $100 \mathrm{mg} \mathrm{l}^{-1}$ formaldehyde, but they were differently affected by half concentration. The swarming of VM2 was completely inhibited at $50 \mathrm{mg} \mathrm{l}^{-1}$ formaldehyde, V16 was still slightly swarming, whereas VA75S3 and VAPFS4 were not sensitive to this concentration (Fig. 2).

The genotypes were characterized by ARDRA (Fig. 3). Two groups of genotypes were observed among the initial isolates. A310, A315 and A317 had the same band pattern with the both restriction enzymes $C f o$ I and Hae III. The second group was also homogeneous, but A331 and A309 were distinct in one of the profiles obtained either with Cfo I or Hae III, respectively. Two types were also obtained with the final isolates, which were quite different from the initial ones. The first group was composed of PF1, PF3, 50F6 and PF18, with exactly the same pattern, plus 75F2 and PF23, which gave an additional restriction fragment of ca. 800 bp with Hae III. The second group corresponded to VAPFS3 and VAPFS4, which were similar to the V. alginolyticus-like reference strains. However, these two isolates had the same RAPD profiles but one obtained with Primer 5, whereas those of the reference strain V16 were quite different (Fig. 4). The profile of VM2 was only showed for Primer 2, but all the RAPD primers gave PCR products of VM2 that were much closer to those of V16 than those of the present isolates (data not shown, the RAPD characterization of VM2 will be published elsewhere).

\subsection{Effect of treatments on Artemia nauplii and pollack larvae}

Two hundred CFU were recovered on Petrifilm per Artemia nauplius fed without probiotic and not treated with formaldehyde (Table 2). This bacterial level was not significantly affected by feeding the nauplii with Bactocell, but it was tenfold increased with Levucell. The 
TCBS counts were not significantly affected by the probiotic treatments. The formaldehyde treatment inhibited completely the bacteria growing on TCBS, whereas the CFU on Petrifilm were decreased at least tenfold. $P$. acidilacti did not grow on Petrifilm, but its colonies were selectively retrieved on MRS agar incubated at $45^{\circ} \mathrm{C}$, with an average of $69 \mathrm{CFU}$ per nauplius fed Bactocell. An additional treatment with formaldehyde decreased fivefold this amount. The recovery of $S$. cerevisiae from Levucell on the selective agar was not affected by the formaldehyde treatment, and that corresponded to ca. $2 \times 10^{2} \mathrm{CFU}$ per nauplius fed with Levucell.

The survival of pollack larvae was not significantly affected by the treatments (Table 3). The best growth rates were obtained when Artemia had been fed with Bactocell during the second step of enrichment. The combination of this enrichment with previous feeding with Levucell increased further the growth rate in comparison with the diet composed of inactive brewers yeast. However, the worse growth rate was observed when the nauplii had been fed with Levucell only during the first enrichment step. The growth rate obtained by feeding Artemia without probiotic was not significantly different from those obtained when Levucell was used at least during the second step of enrichment. The intake of Artemia enriched with Bactocell was more than 4000 nauplii per 29-dph larva, whereas the intake of the other groups was between 2000 and 3000 nauplii larva ${ }^{-1}$.

There was no significant difference among the bacterial counts that averaged out to $10^{5} \mathrm{CFU}$ larva $^{-1}$ and $5 \times 10^{4}$ CFU larva ${ }^{-1}$ on Petrifilm and TCBS agar, respectively. P. acidilactici was retrieved at a level of $10^{5} \mathrm{CFU}$ per larva fed with nauplii enriched with Bactocell, but few tens of CFU larva ${ }^{-1}$ were also recovered on MRS agar after enrichment with Levucell. Though the means were not significantly different, between $2 \times 10^{3} \mathrm{CFU}_{\text {larva }^{-1}}$ and $1.4 \times 10^{4} \mathrm{CFU}_{\text {larva }}{ }^{-1}$ were retrieved on the selective yeast agar, when Levucell had been brought either only during the first enrichment step, or also during the second enrichment step, respectively. 


\section{Discussion}

In previous experiments, the treatment of Artemia nauplii with lactic acid bacteria and Bacillus sp. spores did not improve the growth rate of turbot larvae (Gatesoupe, 1991, 1993). The recovery of the lactic acid bacteria was not studied (Gatesoupe, 1991), but Bacillus sp. was retrieved in turbot larvae at a low level (Gatesoupe, 1993). In the present experiment, the amount of $P$. acidilactici was even higher than the Petrifilm counts in the larvae fed with the enriched nauplii. This artificial dominance was likely decisive for the effect of the probiotic on larval growth.

The amount of Artemia distributed to each experimental group may bring some information about feed efficiency, though there was no statistics. The superior growth rate observed with Bactocell seemed due a higher food consumption rather than due to a better feed efficiency. However, feed efficiency may account for the extra weight gain obtained with the combination Levucell-Bactocell that did not increase further food intake in comparison with Bactocell only. Live yeast are known to stimulate gut maturation in larval sea bass (Tovar et al., 2002), and the strain of S. cerevisiae may have improved the digestion efficiency of nauplii by larval pollack. Dietary live S. cerevisiae improved also feed efficiency in Israeli carp, but to a lesser extent than Streptococcus faecium (Noh et al., 1994). The feed conversion ratio of mrigal fry was also increased with a dietary combination of live S. cerevisiae and Lactobacillus coagulans (Swain et al., 1996).

In the absence of $P$. acidilactici, the yeast did not increase larval growth. Its concentration was inferior to Petrifilm and TCBS counts in the larvae. When the yeast treatment was discontinued during the second enrichment step, the growth rate was even lower than in the control group. This may be due to the concomitant discontinuation of formaldehyde 
disinfection, allowing bacteria to proliferate. Though the means were not significantly different, the highest Petrifilm counts were observed in the group fed with Levucell only during the first enrichment step.

The formaldehyde treatment was required when the nauplii were enriched with Levucell. Indeed this feed additive increased dramatically the bacterial load in Artemia without disinfectant. Yeast and Artemia survived well in 50-100 $\mathrm{mg} \mathrm{l}^{-1}$ formaldehyde, by contrast with $P$. acidilactici. However, Bactocell did not increase bacterial load in comparison with the control treatment without probiotic. That may be due to the concentrated form of the bacterial additive, whereas Levucell contains excipient. Artemia nauplii digest poorly baker’s yeast (Coutteau et al., 1991). It was thus possible to introduce the probiotic yeast early during the first enrichment step, resulting in a significant final yeast intake by the larvae, even without Levucell during the second enrichment step. Bactocell was reserved for the second step without disinfection, enabling thus a combination treatment in spite of the formaldehyde sensitivity of $P$. acidilactici.

However, the treatment used to disinfect Artemia in the present experiment appeared inadvisable, because of the emergence of bacterial strains that could proliferate during cyst incubation in $50 \mathrm{mg}$ formaldehyde $\mathrm{l}^{-1}$ disinfection. These strains were quite different from those initially resistant to $100 \mathrm{mg}$ formaldehyde $\mathrm{l}^{-1}$, and they were still sensitive to this twofold concentration. It could not be recommended to double the concentration of formaldehyde, since some strains were still resistant, and a higher concentration would be detrimental to Artemia survival (Sahul Hameed and Balasubramanian, 2000). There is a risk of transmission of resistance gene to opportunistic strains. Plasmids have been isolated in antibiotic-resistant strains of $V$. alginolyticus (Li et al., 1999; Zanetti et al., 2001). The $V$. alginolyticus-like isolates of the present experiment were genetically distinct from those previously isolated in the same facilities and used as reference. Such bacteria were not 
detected in the initial samples of formaldehyde-treated newly hatched nauplii, since there was no colony growing on TCBS. The selection pressure exerted by the formaldehyde treatment caused likely the emergence of strains more resistant than those previously dominant. Sodium hypochlorite remains the best disinfectant for Artemia cysts (Agh et al., 2001), but it cannot be used during the enrichment process.

Ghioni et al. (1998) tested the effect of formaldehyde on rainbow trout skin cells in vitro. A dose of $20 \mathrm{mg} \mathrm{l}^{-1}$ was sufficient to reduce the lipid content of the cells, with other detrimental effects on their lipid and fatty acid composition. A direct effect of formaldehyde on the larvae was unlikely in the present experiment, due to high dilution, but a detrimental effect on the dietary value of Artemia cannot be excluded.

Though the present disinfection treatment was not advisable, $P$. acidilactici is a promising probiotic for fish larvae in view of its effect as growth promoter. Its combination with $S$. cerevisiae may be valuable, but on condition to prepare a concentrated form that would not jeopardize the bacterial balance in the absence of disinfectant.

\section{Acknowledgements}

Bactocell and Levucell were freely provided by Lallemand SA (F-15130 Saint-Simon, France). Messrs. B. Rochet and H. Durand (Lallemand SA) advised on the characteristics of the probiotics. Thanks are also due to J.L. Gaignon, Y. Normant, B. Petton, P. Quazuguel, L. Quéméner, and M. Suquet for pollack egg supply and rearing advice.

\section{References}


Agh, N., Noori, F., Asefi, A., Sorgeloos, P., 2001. Effects of antibacterial agents on the hatching percentage and bacterial load in the hatching medium of Artemia urmiana cysts. In: Hendry, C.I., Van Stappen, G., Wille, M., Sorgeloos, P. (Eds.), Larvi'01 - Fish \& Shellfish Larviculture Symposium, European Aquaculture Society, Special publication N³0, Oostende, Belgium, 2001, pp. 37-39.

Andlid, T., Blomberg, L., Gustafsson, L., Blomberg, A., 1999. Characterization of Saccharomyces cerevisiae CBS 7764 isolated from rainbow trout intestine. System. Appl. Microbiol. 22, 145-155.

Chatain, B., Ounais-Guschemann, N., 1990. Improved rate of initial swim bladder inflation in intensively reared Sparus auratus. Aquaculture 84, 345-353.

Coutteau, P., Lavens, P., Sorgeloos, P., 1990. Baker’s yeast as a potential substitute for live algae in aquaculture diets: Artemia as a case study. J. World Aquacult. Soc. 21, 1-9.

Dees, P.M., Ghiorse, W.C., 2001. Microbial diversity in hot synthetic compost as revealed by PCR-amplified rRNA sequences from cultivated isolates and extracted DNA. FEMS Microbiol. Ecol. 35, 207-216.

Felsenstein, J., 1996. Inferring phylogenies from protein sequences by parsimony, distance, and likelihood methods. In: Doolittle, R.F. (Ed.), Computer Methods for Macromolecular Sequence Analysis. Methods in Enzymology vol. 266, Academic Press, Orlando FL, pp. 418-427.

Filho-Lima, J.V., Vieira, E.C., Nicoli, J.R., 2000. Antagonistic effect of Lactobacillus acidophilus, Saccharomyces boulardii and Escherichia coli combinations against experimental infections with Shigella flexneri and Salmonella enteritidis subsp. typhimurium in gnotobiotic mice. J. Appl. Microbiol. 88, 365-370. 
Gaignon, J.L., Petton, B., Quéméner, L., 1998. Influence de l’hydrodynamique des bassins sur la survie et la croissance des larves de turbot (Psetta maxima). Bull. Fr. Pêche Piscic. 350351, 303-323.

Gatesoupe, F.J., 1990. The continuous feeding of turbot larvae, Scophthalmus maximus, and control of the bacterial environment of rotifers. Aquaculture 89, 139-148.

Gatesoupe, F.J., 1991. The effect of three strains of lactic bacteria on the production rate of rotifers, Brachionus plicatilis, and their dietary value for larval turbot, Scophthalmus maximus Aquaculture 96, 335-342.

Gatesoupe, F.J., 1993. Bacillus sp. spores as food additive for the rotifer Brachionus plicatilis: Improvement of their bacterial environment and their dietary value for larval turbot, Scophthalmus maximus L. In: Kaushik, S.J., Luquet, P. (Eds.), Fish Nutrition in Practice, 4th Int. Symp. Fish Nutrition and Feeding, 24-27 June 1991, Biarritz (France). Institut National de la Recherche Agronomique, Paris (France), Colloq. INRA, no. 61, pp. 561-568.

Gatesoupe, F.J., 1997. Siderophore production and probiotic effect of Vibrio sp. associated with turbot larvae, Scophthalmus maximus. Aquatic Living Resources 10, 239-246.

Gatesoupe, F.J., 1999. The use of probiotics in aquaculture. Aquaculture 180, 147-165.

Gatesoupe, F.J., Lambert, C., Nicolas, J.L., 1999. Pathogenicity of Vibrio splendidus strains associated with turbot larvae, Scophthalmus maximus. Journal of Applied Microbiology 87, 757-763.

Ghioni, C., Tocher, D.R., Sargent, J.R., 1998. Effects of dichlorvos and formalin on fatty acid metabolism of rainbow trout (Oncorhynchus mykiss) skin cells in primary culture. Fish Physiol. Biochem. 18, 241-252. 
Gildberg, A., Mikkelsen, H., 1998. Effects of supplementing the feed to Atlantic cod (Gadus morhua) fry with lactic acid bacteria and immuno-stimulating peptides during a challenge trial with Vibrio anguillarum. Aquaculture 167, 103-113.

Gildberg, A., Mikkelsen, H., Sandaker, E., Ringø, E., 1997. Probiotic effect of lactic acid bacteria in the feed on growth and survival of fry of Atlantic cod (Gadus morhua). Hydrobiologia 352, 279-285.

Halami, P.M., Chandrashekar, A., Joseph, R., 1999. Characterization of bacteriocinogenic strains of lactic acid bacteria in fowl and fish intestines and mushroom. Food Biotechnology 13, 121-136.

Kummerle, N., Feucht, H.H., Kaulfers, P.M., 1996. Plasmid-mediated formaldehyde resistance in Escherichia coli: characterization of resistance gene. Antimicrob. Agents Chemother. 40, 2276-2279.

Lambert, C., Nicolas, J.L., Cilia, V., Corre, S., 1998. Vibrio pectenicida sp. nov., a pathogen of scallop (Pecten maximus) larvae. Int. J. Syst. Bact. 48 481-487.

Lavens, P., Sorgeloos, P., 2000. Experiences on importance of diet for shrimp postlarval quality. Aquaculture 191, 169-176.

Li, J., Yie, J., Foo, R.W.T., Ling, J.M.L., Xu, H.S., Woo, N.Y.S., 1999. Antibiotic resistance and plasmid profiles of vibrio isolates from cultured silver sea bream, Sparus sarba. Marine Pollution Bulletin 39, 245-249.

Mohanty, S.N., Swain, S.K., Tripathi, S.D., 1996. Rearing of catla (Catla catla Ham.) spawn on formulated diets. J. Aqua. Trop. 11, 253-258.

Noh, S.H., Han, I.K., Won, T.H., Choi, Y.J., 1994. Effect of antibiotics, enzyme, yeast culture and probiotics on the growth performance of Israeli carp. Korean J. Anim. Sci. 36, 480486. 
Nikoskelainen, S., Salminen, S., Bylund, G., Ouwehand, A.C., 2001a. Characterization of the properties of human- and dairy-derived probiotics for prevention of infectious diseases in fish. Appl. Environ. Microbiol. 67, 2430-2435.

Nikoskelainen, S., Ouwehand, A.C., Salminen, S., Bylund, G., 2001b. Protection of rainbow trout (Oncorhynchus mykiss) from furunculosis by Lactobacillus rhamnosus. Aquaculture 198, 229-236.

Sahul Hameed, A. S., Balasubramanian, G., 2000. Antibiotic resistance in bacteria isolated from Artemia nauplii and efficacy of formaldehyde to control bacterial load. Aquaculture 183, 195-205.

Schrøder, K., Clausen, E., Sandberg, A.M., Raa, J., 1980. Psychrotrophic Lactobacillus plantarum from fish and its ability to produce antibiotic substances. In: Connell, J.J. (Ed.), Advances in Fish Science and Technology, the Jubilee Conference of the Torry Research Station, 23 July 1979, Aberdeen, Scotland. Fishing News Books Ltd., Farnham, Surrey, England, pp. 480-483.

Skjermo, S., Vadstein, O., 1993. The effect of microalgae on skin and gut bacterial flora of halibut larvae. In: Reinertsen, H., Dahle, L.A., Jørgensen, L., Tvinnereim, K. (Eds.), Fish Farming Technology. $1^{\text {st }}$ Int. Conf. on Fish Farming Technology, 9-12 Aug 1993, Trondheim, Norway. Balkema, Rotterdam, pp. 61-67.

Spicher, G., Peters, J., 1976. Resistenz mikrobieller Keime gegenüber Formaldehyd. I. Vergleichende quantitative Untersuchungen an einigen ausgewählten Arten vegetativer Bakterien, bakterieller Sporen, Pilze, Bakteriophagen und Viren. Zentralbl. Bakteriol., Mikrobiol. Hyg., 1 Abt., Orig. B 163, 486-508.

Suquet, M., 2001. Le lieu jaune (Pollachius pollachius). Biologie, pêche, marché et potentiel aquacole. Ifremer, Brest, $36 \mathrm{pp}$. 
Suquet, M., Petton, B., Normant, Y., Dosdat, A., Gaignon, J.L., 1996. First rearing attempts of pollack, Pollachius pollachius. Aquat. Living Resour. 9, 103-106.

Swain, S.K., Rangacharyulu, P.V., Sarkar, S., Das, K.M., 1996. Effect of a probiotic supplement on growth, nutrient utilization and carcass composition in mrigal fry. Journal of Aquaculture (Cent. Inst. Fresh Water Aquacult., Kausalyaganga, Bhubaneshwar, Orissa, India) 4, 29-35.

Sokal, D.M., Rohlf, F.J., 1969. Biometry. Citizen, San Francisco, 776 pp.

Tovar Ramirez, D., Zambonino Infante, J.L., Gatesoupe, F.J., Vazquez Juarez, R., 2000.

Preliminary study of the potential of yeasts as probiotics for the European sea bass larvae, Dicentrarchus labrax. In: Flos, R., Creswell, L. (Eds.), Responsible Aquaculture in the New Millenium, Abstracts \& Contributions of the International Conference Aqua 2000, 2-6 May, Nice, France. European Aquaculture Society Special Publication N² 28. EAS, Oostende, Belgium, p. 714.

Tovar, D., Zambonino, J., Cahu, C., Gatesoupe, F.J., Vazquez Juarez, R., Lésel, R., 2002. Effect of live yeast incorporation in compound diet on digestive enzyme activity in sea bass (Dicentrarchus labrax) larvae. Aquaculture 204, 113-123.

van der Meeren, T., Lønøy, T., 1998.Use of mesocosms in larval rearing of saithe [Pollachius virens (L.)], goldsinny [Ctenolabrus rupestris (L.)], and corkwing [Crenilabrus melops (L.)]. Aquacult. Eng. 17, 253-260.

Verschuere, L., Rombaut, G., Huys, G., Dhont, J., Sorgeloos, P., Verstraete, W., 1999. Microbial control of the culture of Artemia juveniles through preemptive colonization by selected bacterial strains. Appl. Environ. Microbiol. 65, 2527-2533.

Zanetti, S., Spanu, T., Deriu, A., Romano, L., Sechi, L.A., Fadda, G., 2001. In vitro susceptibility of Vibrio spp. isolated from the environment. Int. J. Antimicrob. Agents 17, 407-409. 
Table 1

Initial effect of formaldehyde treatment of Artemia cysts on hatching rate (in nauplii per mg of cysts) and bacterial counts after hatching (CFU nauplius ${ }^{-1}$ ); \pm standard error; n.d. not detected; n.s. not significant; parametric ANOVA, unless KW specified for Kruskall-Wallis procedure.

\begin{tabular}{lllll}
\hline Formaldehyde dose & $0 \mathrm{mg} \mathrm{l}^{-1}$ & $50 \mathrm{mg} \mathrm{l}^{-1}$ & $100 \mathrm{mg} \mathrm{l}^{-1}$ & Significance \\
\hline Hatching rate & $152 \pm 34$ & $199 \pm 15$ & $181 \pm 10$ & n.s. \\
\hline Petrifilm counts & $22710 \pm 4103^{\mathrm{a}}$ & $1.4 \pm 0.3^{\mathrm{b}}$ & $0.7 \pm 0.1^{\mathrm{c}}$ & $* * * P<0.001(\mathrm{KW})$ \\
\hline TCBS counts & $7547 \pm 2290$ & n.d. & n.d. & $* * P<0.05(\mathrm{KW})$ \\
\hline
\end{tabular}


Table 2

Effect of probiotic and formaldehyde treatments of Artemia nauplii on microbial counts (CFU nauplius $^{-1} \pm$ standard error; n.a. not applicable; n.d. not detected; n.s. not significant; KW specified for Kruskall-Wallis procedure; ${ }^{\S}$ parametric ANOVA after exclusion of nil groups).

\begin{tabular}{|c|c|c|c|c|}
\hline Agar & Petrifilm & TCBS & MRS & $\begin{array}{l}\text { Sabouraud + } \\
\text { antibiotics }\end{array}$ \\
\hline Control & $202 \pm 99^{b}$ & $30 \pm 11^{\mathrm{a}}$ & n.d. & n.d. \\
\hline Formaldehyde & $17 \pm 17^{\mathrm{c}}$ & n.d. & n.d. & n.d. \\
\hline Bactocell & $109 \pm 38^{b}$ & $36 \pm 9^{a}$ & $69 \pm 31^{a}$ & n.d. \\
\hline $\begin{array}{l}\text { Bactocell + } \\
\text { formaldehyde }\end{array}$ & $0.05 \pm 0.02^{\mathrm{c}}$ & n.d. & $14 \pm 5^{b}$ & n.d. \\
\hline Levucell & $1877 \pm 959^{a}$ & $72 \pm 46^{\mathrm{a}}$ & n.d. & $235 \pm 82^{\mathrm{a}}$ \\
\hline $\begin{array}{l}\text { Levucell + } \\
\text { formaldehyde }\end{array}$ & $0.3 \pm 0.3^{c}$ & n.d. & n.d. & $255 \pm 95^{\mathrm{a}}$ \\
\hline Significance (KW) & $* P<0.05$ & $* P<0.05$ & $* * P<0.01$ & $* * P<0.01$ \\
\hline ANOVA $^{\S}$ & n.a. & n.s. & $* P<0.05$ & n.s. \\
\hline
\end{tabular}


Effect of the probiotic treatment of Artemia nauplii on the final survival rate, mean weight, prey intake, and microbial counts of pollack larvae ( \pm standard error; n.a. not applicable; n.d. not detected; n.s. not significant; parametric ANOVA, , unless KW specified for Kruskall-Wallis procedure).

\begin{tabular}{|c|c|c|c|c|c|c|c|}
\hline Nauplii enrichment & $\mathrm{BC}$ & $\mathrm{LC}$ & BL & LL & $\mathrm{BP}$ & LP & Significance \\
\hline $1^{\text {st }}$ step of enrichment & brewers yeast & Levucell & brewers yeast & Levucell & brewers yeast & Levucell & \\
\hline $2^{\text {nd }}$ step of enrichment & no probiotic & no probiotic & Levucell & Levucell & Bactocell & Bactocell & \\
\hline Survival (\%) & $12 \pm 4$ & $12 \pm 3$ & $33 \pm 7$ & $25 \pm 5$ & $15 \pm 5$ & $24 \pm 5$ & n.s. \\
\hline Weight (mg) & $4.7 \pm 0.2^{c}$ & $3.3 \pm 0.2^{\mathrm{d}}$ & $5.1 \pm 0.2^{c}$ & $5.3 \pm 0.3^{c}$ & $6.1 \pm 0.3^{b}$ & $8.1 \pm 0.3^{\mathrm{a}}$ & $* * * P<0.001$ \\
\hline Artemia per 29-dph larva ${ }^{\S}$ & $3.0 \times 10^{3}$ & $3.1 \times 10^{3}$ & $2.2 \times 10^{3}$ & $2.8 \times 10^{3}$ & $4.7 \times 10^{3}$ & $4.4 \times 10^{3}$ & n.a. \\
\hline $\begin{array}{l}\text { Petrifilm counts } \\
\left(\times 10^{4} \text { CFU larva }^{-1}\right)\end{array}$ & $11 \pm 0.6$ & $18 \pm 9$ & $8 \pm 5$ & $12 \pm 11$ & $2 \pm 0.8$ & $8 \pm 4$ & n.s. \\
\hline $\begin{array}{l}\text { TCBS counts } \\
\left(\times 10^{4} \text { CFU larva }{ }^{-1}\right)\end{array}$ & $2 \pm 2$ & $10 \pm 5$ & $3 \pm 2$ & $11 \pm 11$ & $3 \pm 2$ & $2 \pm 2$ & n.s. \\
\hline MRS counts (CFU larva ${ }^{-1}$ ) & n.d. & n.d. & $18 \pm 10^{\mathrm{b}}$ & $27 \pm 23^{b}$ & $\left(1.3 \pm 1^{\mathrm{a}}\right) \times 10^{5}$ & $\left(2.1 \pm 0.7^{\mathrm{a}}\right) \times 10^{5}$ & $* P<0.05(\mathrm{KW})$ \\
\hline $\begin{array}{l}\text { Sabouraud }+ \text { antibiotics } \\
\left(\times 10^{3} \text { CFU larva }{ }^{-1}\right)\end{array}$ & n.d. & $2 \pm 1^{\mathrm{a}}$ & $14 \pm 6^{\mathrm{a}}$ & $14 \pm 5^{\mathrm{a}}$ & n.d. & $2 \pm 0.4^{\mathrm{a}}$ & $\begin{array}{l}* * P<0.01 \\
(\mathrm{KW})\end{array}$ \\
\hline
\end{tabular}

\footnotetext{
${ }^{\S}$ Computed as the total amount 1 dph Artemia distributed to the larvae from 13 dph onwards, and divided by the number of larvae that survived
} at $29 \mathrm{dph}$. 


\section{Figures}

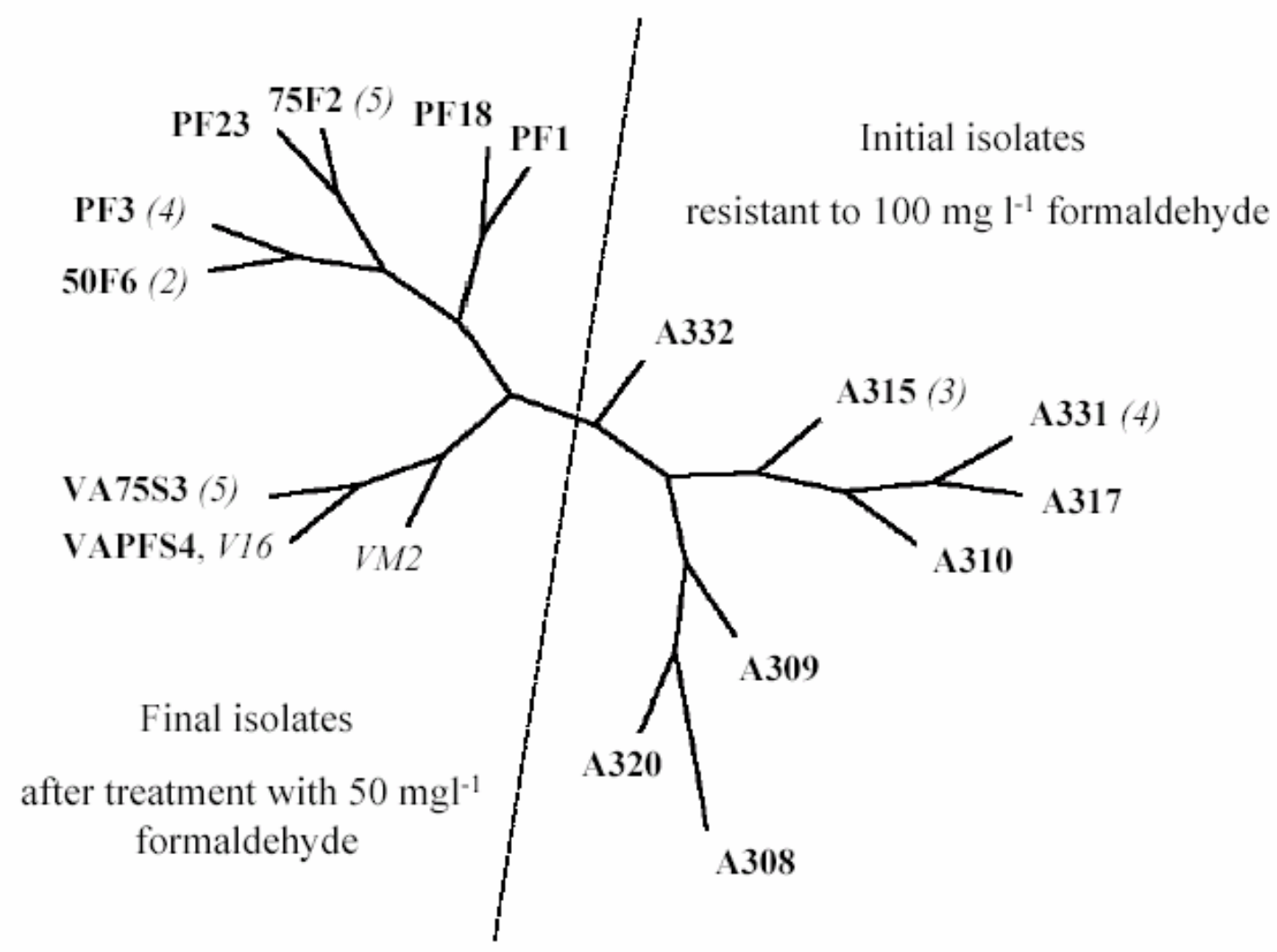

Fig. 1. Phenotypic dendrogram of bacterial isolates obtained from Artemia nauplii after cyst disinfection with formaldehyde. The dotted line separated the initial isolates (right) from the final ones (left). When several isolates corresponded to the same profile, their number was indicated in brackets. VM2 and V16 were added to the dendrogram, as reference strains. 


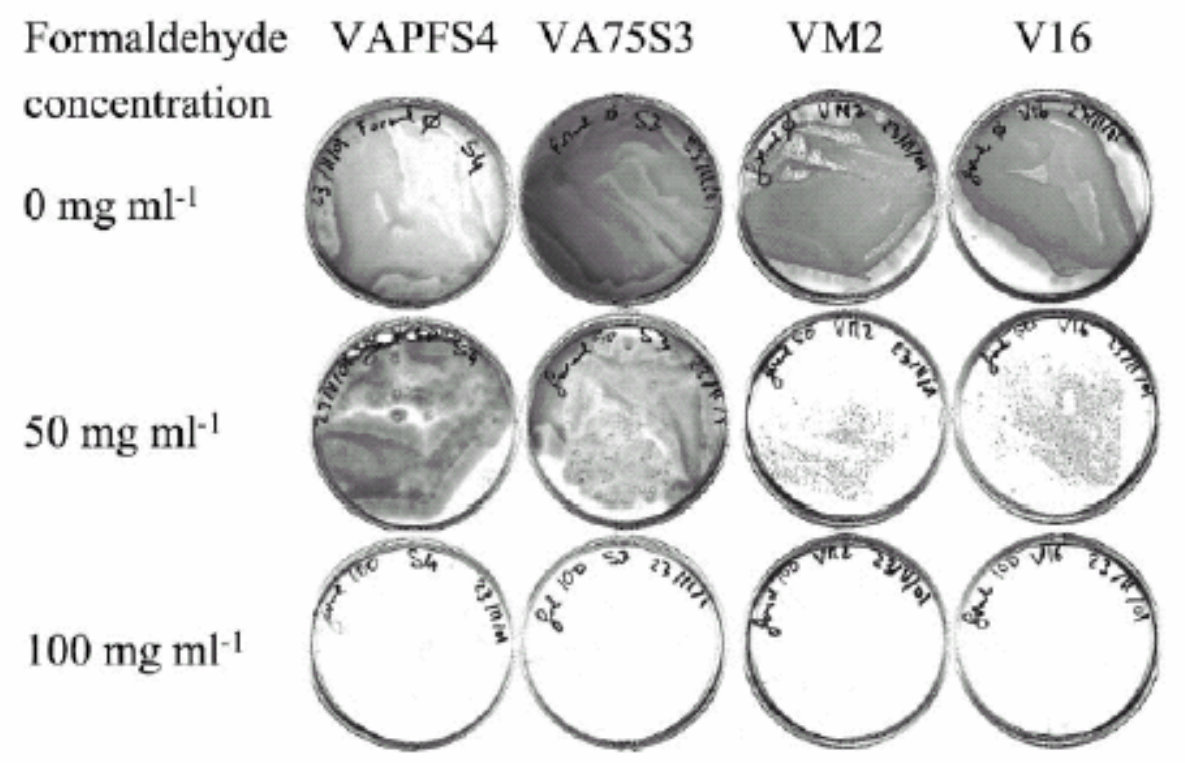

Fig. 2. The effect of formaldehyde concentration on growth and swarming of V. alginolyticuslike strains on PCA. 

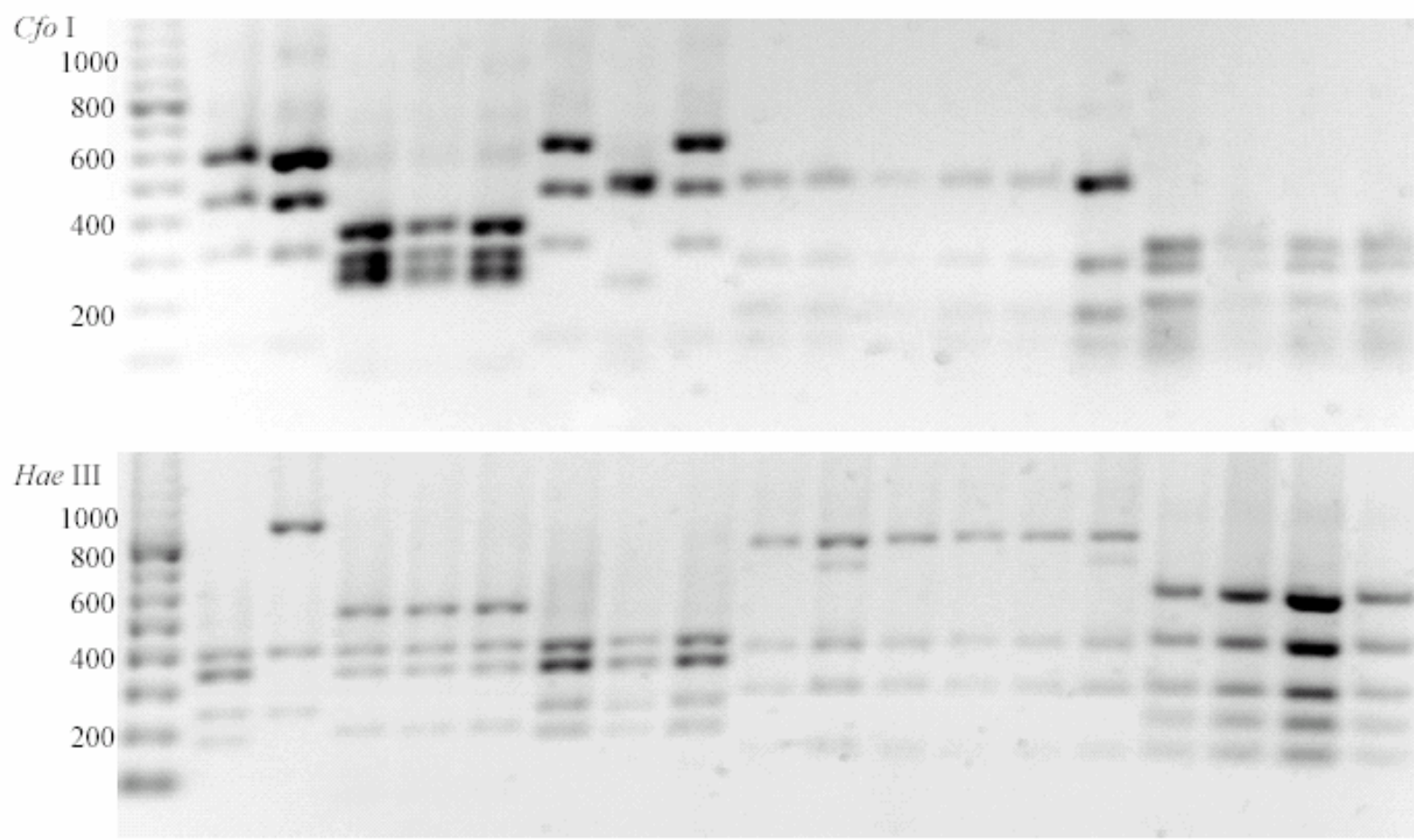

Fig. 3. ARDRA of the bacterial isolates obtained from Artemia nauplii after cyst disinfection with formaldehyde; M: Base-Pair ladder (BP). 


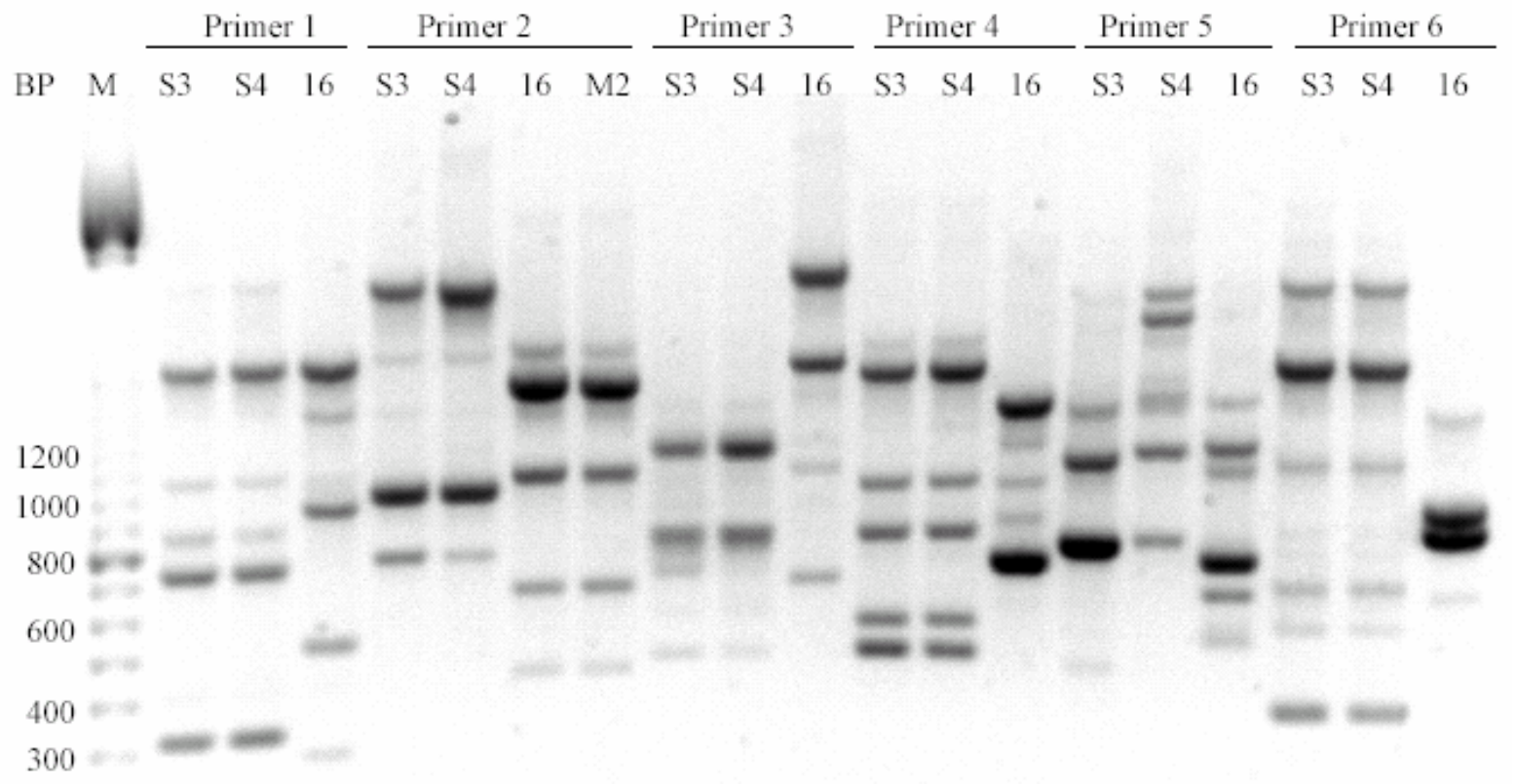

Fig. 4. RAPD analysis of V. alginolyticus-like strains; M: Base-Pair ladder (BP); S3:

VA75S3; S4: VAPFS4; 16: V16; M2: VM2. 